\title{
STUDI DESKRIPTIF LAYANAN BIMBINGAN KARIR PADA SEKOLAH MENENGAH KEJURUAN SE-KOTA TARAKAN
}

\author{
Yenni Maryani, Hendra Pribadi, Urotul Aliyah \\ Fakultas Keguruan dan Ilmu Pendidikan, Universitas Borneo Tarakan \\ yennimaryani22@gmail.com
}

\begin{abstract}
Problem formulation in this research is how the implementation of career guidance services implemented by teachers BK at Vocational School Tarakan City. This study aims to determine the implementation of career guidance services implemented by teachers $B K$ at vocational high schools as Tarakan City.

The type of this research is descriptive survey research. The population in this study were 8 BK teacher at Vocational High School and the sampel was 2 BK teachers using random sampling. Methods of data collection using questionnaires and interviews. Data analysis technique in this research is percentage analysis.

The results showed that the implementation of career guidance services in Vocational High School, reaching 85,55\%. This means that implementation of career services program is in accordance with the provisions and mechanisms that have been set, so the school, by looking at aspects of planning, organizing, implementation, evaluation and follow-up.
\end{abstract}

\section{Keywords : Implementation of Career Guidance Services}

\section{PENDAHULUAN}

Sekolah menengah kejuruan (SMK) merupakan salah satu bentuk satuan pendidikan formal yang menyelenggarakan pendidikan kejuruan pada jenjang pendidikan menengah sebagai lanjutan dari SMP, MTs, atau bentuk lain yang sederajat. Sekolah dijenjang pendidikan dan kejuruan dapat bernama sekolah menengah kejuruan (SMK) atau Madrasah aliyah kejuruan (MAK), atau bentuk lain yang sederajat (Undang-undang Sisdiknas Nomor 20 tahun 2003).

SMK memiliki banyak program keahlian yang disesuaikan dengan kebutuhan dunia kerja yang ada serta permintaan masyarakat dan pasar. Pendidikan kejuruan adalah pendidikan menengah yang mempersiapkan siswa agar siap bekerja dalam bidang keahliannya. Kurikulum SMK dibuat

agar siswa siap untuk masuk kedunia kerja. kurikulum yang ada di SMK disusun sedemikian rupa sesuai dengan kebutuhan dunia kerja yang ada. Hal ini dilakukan agar siswa tidak mengalami kesulitan dalam memasuki dunia kerja. Dengan masa studi sekitar tiga tahun, lulusan SMK diharapkan mampu untuk bekerja sesuai dengan keahlian yang telah ditekuni. Maka dibutuhkan guru bimbingan dan konseling mengatasi dan menentukan jalan keluar untuk peserta didik.

Bimbingan dan konseling dalam suatu sekolah dipandang sangat penting karena adanya fakta yang bisa dihindarkan yakni setiap siswa memiliki pemikiran, sikap, kepribadian yang berbeda, dan juga bahwa setiap siswa atau individu mengalami perkembangan dalam berbagai aspek dalam dirinya. Bahkan dapat menimbulkan perasaan yang berbeda pada diri setiap siswa yang akhirnya menjadi permasalahan dalam dirinya.

Keberadaan bimbingan dan konseling di sekolah yang berperan untuk membantu siswa yang mengalami kesulitan dalam berbagai hal terutama dalam perencanaan karir dan masalah kekeliruan jurusan atau program studi harus senantiasa mendapat perhatian yang serius agar dapat segera diatasi. Oleh karena itu, bimbingan karir menjadi salah satu bentuk layanan bimbingan yang penting diselenggarakan di sekolah. Pada masa ini dalam layanan bimbinga karir yang meskipun telah teruji dalam memfasilitasi transisi dan dunia sekolah ke dunia kerja hanya sedikit sekali siswa yang memiliki akses akan bimbingan, hingga menyebabkan seperempat 
angkatan muda kini menganggur dan masih banyak lagi yang mengerjakan pekerjaan yang tidak sesuia dengan keterampilan yang dimilikinya.

Tugas seorang guru bimbingan dan konseling adalah membantu untuk mengatasi dan menemuka jalan keluar suatu permasalahan siswa. Namun bukan hanya itu saja, guru BK juga dapat memberikan layanan berupa memberikan bantuan untuk menemukan dan memahami pribadi siswa agar dapat mengetahuai kekurangan dan kelebihan pada dirinya, memberikan bimbingan kepada siswa agar senantiasa bisa belajar yang terpenting adalah proses belajar sehingga siswa mengalami secara langsung terhadap hal yang dipelajarinya karna siswa dalam memahami pelajaran berbeda satu dengan yang lain, guru BK memberikan bimbingan kepada siswa untuk menentukan karir atau menata kehidupan yang lebih baik. Hal ini penting karena siswa yang bahkan sama sekali tidak memahami orientasi dari hasil belajarnya sendiri terkait dengan mengambil keputusan. Guru BK tidak hanya beberurusan dengan siswa bermasalah saja, tapi juga membantu siswa untuk menentukan dan memecahkan masalah pada diri siswa, dan memberikan dorongan dan motivasi dalam mengejak citacita.

Menurut Wardati dan Jauhar yang perlu diperhatikan dalam pemberian layanan bimbingan kepada siswa, harus tetap fokus pada empat bidang layanan bimbingan. Bidang kegiatan bimbingan dan konseling ini dapat dikelompokkan yaitu : 1). Bimbingan Pribadi. 2). Bidang sosial. 3). Bimbingan Belajar. 4).

Bimbingan karir. Jenis layanan bimbangan dan konseling yaitu layanan orientasi, layanan informasi, layanan penempatan dan penyaluran, layanan pembelajaran, layanan konseling individu, layanan konseling kelompok, layanan bimbingan kelompok, sedangkan kegiatan pendukung : aplikasi instrumen, himpuanan data, konferensi kasus, kunjungan rumah, alih tangan kasus..

Bimbingan karir menurut Syamsu Yusuf (2009) merupakan sebuah upaya pemberian bantuan terhadap individu agar dapat mengenal dan memahami dirinya secara mendalam, mengenal dunia kerja dan mengembangkan masa depan yang sesuai dengan kehidupan yang diharapkannya. Tujuan diberikan bimbingan karir yakni individu mampu menentukan dan mengambil keputusan karirnya secara tepat lalu dapat bertanggung jawab atas keputusan yang diambilnya sehingga dapat mengaktualisasikan diri dengan baik.

Berdasarkan kepada temuan penelitian di beberapa SMK di Jawa Barat Syamsu Yusuf LN dalam Nurihsan (2016) tentang tugas-tugas perkembangan siswa dan ekpetasinya, serta masalah yang diduga sering dialami remaja, maka aspekaspek yang perlu mendapatkan layanan responsif dalam bidang karir seperti kurang memahami cara memilih program studi yang cocok dengan kemampuan dan minat, kurang mempunyai motivasi untuk mencari informasi tentang dunia kerja, masih bingung untuk memilih pekerjaan, masih kurang mampu memilih pekerjaan yang sesuai dengan kemampuan bakat dan minat, merasa cemas untuk mendapat pekerjaan setelah tamat sekolah, belum memiliki pilihan perguruan tinggi tertentu, jika setelah tamat tidak masuk dunia kerja.

Hasil wawancara di SMKN 2 Tarakan terdapat beberapa hambatan dalam pelaksanaan layanan karir seperti : ruang bimbingan dan konseling hanya terdiri dari ruang kerja dan ruang tamu, sehingga pelaksanaan layanan karir dilakukan di aula sekolah atau di ruang kelas. layanan bimbingan karir dikhususkan kepada kelas XII seperti klasikal informasi tentang karir, kerja sama dengan universitas luar, membagikan brosur-brosur, dan lowongan-lowongan pekerjaan.

Berdasarkan hasil wawancara awal dapat disimpulkan dapat diketahui bahwa pelaksanaan layanan bimbingan karir, yaitu kesiapan guru bimbingan dan konseling dalam memberikan layanan bimbingan karir masih banyak hambatan dalam penyampaian, fasilitas dan sarana prasarana bimbingan karir kurang memadai. Selain itu, ruangan bimbingan karir yang terbatas sehingga layanan bimbingan karir dilakukan UKS, perpustakaan atau di ruang kelas.

Pemasalahan siswa yang dihadapi cukup banyak jumlahnya menjelang kelulusan, permasalahan yang muncul pada bimbingan karir atara lain : pemahaman siswa tentang informasi dunia pekerjaan masih siswa kurang, siswa masih bingung untuk memilih pekerjaan, siswa masih kurang mampu memiliki pekerjaan yang sesuai dengan kemampuan minat dan bakat. Oleh karena itu peran guru BK dalam memberikan layanan kesiapan karir sangat penting diperlukan dalam membantu memecahkan permasalahan diatas. Melalaui 
bimbingan karir diharapkan siswa mampu menentukan dan mengambil keputusan karirnya secara tepat, sehingga dapat bertanggung jawab atas keputusan yang diambilnya sehingga dapat megaktualisasikan diri dengan baik, serta mendapatkan bantuan dalam pemahaman yang lebih tepat tentang keadaan dan kemampuannya, kesadaran terhadap nilainilai yang ada pada dirinya dan masyarakat, pembimbingan terhadap studi yang dijalaninya, pengenalan terhadap berbagai macam pekerjaan, persiapan yang matang untuk memasuki dunia untuk itu bimbingan dapat menjadi media bagi siswa untuk berbagi mengenai masalah-masalah karir dan yang terkait dengan hal karir. Berdasarkan fenomena tersebut peneliti tertarik untuk meneliti "Pelaksanaan Layanan Bimbingan Karir Di SMK Se-Kota Tarakan"

\section{TUJUAN PENELITIAN}

Tujuan yang hendak dicapai dalam penelitian ini adalah untuk mengetahui Pelaksanaan Layanan Bimbingan Karir yang dilaksanakan oleh guru BK pada Sekolah Menengah Kejuruan Se-Kota Tarakan.

\section{METODE PENELITIAN}

Jenis penelitian ini adalah penelitian survei yang bersifat deskriptif. Penelitian survei adalah penelitian yang mengambil dari satu populasi dan menggunakan angket sebagai alat pengumpulan data yang pokok. Suatu survei deskriptif berupa menjelaskan atau mencatat kondisi atau sikap untuk menjelaskan apa yang ada saat ini Morissan dalam Kelana (2016).

\section{POPULASI DAN SAMPEL PENELITIAN}

Adapun untuk keperluan penelitian ini, yang menjadi populasinya adalah seluruh SMK Se- Kota Tarakan yang totalnya berjumlah 8 sekolah. Cara pengambilan sampel dalam penelitian ini adalah dengan cara random sampling, karna pengambilan anggota sampel dari populasi dilakukan secara acak dengan melakukan undian berdasarkan dari nomor daftar sekolah teknik yang sudah ditentukan jumlah sampelnya yang akan diambil.

Berdasarkan angka populasi dari 8 SMK SeKota Tarakan, maka peneliti mengambil sampel sejumlah 2 sekolah yang terdiri dari 2 sekolah negeri.

\section{INSTRUMEN PENELITIAN}

1. Uji Kesahihan butir (Validitas)

Validitas instrumen berhubungan dengan kesesuaian dan kecerdasan fungsi alat ukur digunakan. Alat ukur dikatakan valid jika benar-benar menjawab tentang variabel yang diukur. Validitas instrumen dalam penelitian ini dilakukan dengan uji validitas konstruksi.

a. Uji validitas konstruksi

Menurut Sugiyono (2015), menguji validitas butir-butir instrumen, dapat digunakan pendapat dari para ahli (profesionel judgment). Dalam hal ini setelah instrumen di konstruksikan tentang aspek-aspek yang akan diukur dengan ahli. Para ahli diminta pendapatnya tentang instrumen yang telah disusun itu. Pada ahli akan memutuskan apakah instrumen dapat digunakan tanpa perbaikan, atau ada perbaikan atau diubah total.

\section{TEKNIK ANALISIS DATA}

Teknik analisis data yang digunakan dalam penelitian ini adalah teknik analisis statistik deskriptif menggunakan rumus persentase yang dimana untuk mengetahui hasil survey, setelah diketahui persentasenya dari hasil angket pelaksanaan layanan bimbingan karir dari responden, maka setiap variabel dikategorikan sebagai standar untuk menentukan kategori Pelaksanaan layanan bimbingan karir.

\section{Rumus Persentase}

Menurut Sugiyono (2015), Teknik Analisa Data Deskriptif Presentatif yaitu menguraikan dengan kata-kata yang dibantu tabel frekuensi. Analisis deskriptif dimaksudkan untuk mengetahui pelaksanaan layanan bimbingan karir pada SMK Se-Kota Tarakan, dengan menggunakan tabel distribusi frekuensi dan persentase dengan rumus persentase yaitu :

$$
P=\frac{f}{N} \times 100 \%
$$

Dimana :

$\mathrm{P}$ : Persentase $\mathrm{f}$ : Frekuensi yang dicari persentase $\mathrm{N}$ : Jumlah subjek (sampel).

\section{HASIL DAN PEMBAHASAN}

Hasil penelitian digambarkan dengan diawali penggambaran keseluruhan pelaksanaan program layanan bimbingan karir, 
kemudian dilanjutkan dengan gambaran perindikator Pelaksanaan Program Layanan Bimbingan Karir.

\section{Analisis Deskriptif Pelaksanaan Program Layanan Bimbingan Karir Pada Sekolah Menengah Kejuruan se Kota Tarakan}

Gambaran menyeluruh tentang

Pelaksanaan layanan bimbingan karir yang dilaksanakan guru BK di SMK se Kota Tarakan ditinjau dari empat aspek. Yakni : aspek perencanaan, aspek pergorganisasian, aspek pelaaksanaan, aspek evaluasi dan tindak lanjut. Berikut ini hasil analisis pelaksanaan setiap aspek berdasarkan hasil jawaban angket guru BK di SMK se Kota Tarakan sebagai berikut :

Berdasarkan tabel 4.1 dapat diketahui bahwa pelaksanaan program layanan bimbingan karir yang dilaksanakan guru BK pada SMK se kota tarakan yaitu aspek perencanaan $85 \%$, aspek pengorganisasian persentasenya $91 \%$, aspek pelaksanaan dengan persentase 85.71 , aspek evaluasi dan tindak lanjut $57,14 \%$, berdasarkan data tersebut diketahui rata-rata pelaksanaan program layanan karir pada SMK se kota Tarakan yakni $85.55 \%$.

\section{Gambaran Per-Indikator Pelaksanaan Program Layanan Pada Sekolah Menengah Kejuruan se Kota Tarakan}

Gambaran per-indikator pelaksanaan program layanan bimbingan karir, terdiri atas empat indikator yaitu perencanaan, pergorganisasian, pelaksanaan, evaluasi dan tindak lanjut berdasarkan kategorisasi pelaksanaan layanan bimbingan karir.

\section{KESIMPULAN}

Berdasarkan hasil penelitian menunjukkan bahwa pelaksanaan layanan bimbingan karir pada Sekolah Menengah Kejuruan, maka dapat disimpulkan bahwa pelaksanaan layanan bimbingan karir pada Sekolah Menengah Kejuruan se-Kota tarakan, mencapai $85.55 \%$. Artinya pelaksanaan program layanan karir sudah sesuai dengan ketentuan dan mekanisme yang telah ditetapkan, sehingga hasilnya dapat digunakan dalam melaksanakan program layanan bimbingan karir di Sekolah, dengan melihat aspek perencanaan, pengorganisasian, pelaksanaan, evaluasi, dan tindak lanjut.

\section{SARAN}

Berdasarkan penelitian yang telah dilakukan maka dapat diajukan saran sebagai berikut:

1. Bagi guru BK, diharapkan menjadi masukan dalam pelaksanaan program layanan bimbingan karir dan bisa menghadapi berbagai permasalahan yang berkaitan dengan aspek perencanaan, pengorganisasian, pelaksanaan, evaluasi dan tindak lanjut.

2. Bagi peneliti,diharapkan hasil penilitian ini dijadikan bahan panduan atau referensi untuk mengkaji lebih lanjut dengan cara menindak lajuti perkembangan kedepannya mengenai program layanan bimbingan karir disekolah.

3. Bagi mahasiswa, diharapkan dapat dijadikan sebagai bahan pelajaran atau referansi dalam menempuh proses bealajar dan menjadi masukan kedepan untuk menjadi gutu BK yang lebih profesional.

\section{DAFTAR PUSTAKA}

Arikunto, Suharsimi. 2010. Prosedur Penelitian. Jakarta: Rineka Cipta

Ahmadi, Rulam. 2014. Metodologi Penelitian Kualitatif. Yogyakarta: Ar- Ruzz Media

Azwar, Saifuddin. 2014. Penyusunan Skala Psikologi. Yogyakarta: Pustaka Pelajar

Gani, Ruslan. 2012. Bimbingan karir. Bandung: Angkasa

Juarenangsih. 2015. Studi Tentang Pelaksanaan Program Layanan BK Kelas VII SMP Negeri 7 Tarakan. Skripsi. Universitas Borneo Tarakan.

Kelana, Galih Harya. 2016. Studi Tentang Persepsi Siswa Terhadap Guru BK Kelas VIII Di SMP Negeri 8 Tarakan. Skripsi. Universitas Borneo Tarakan.

Nursalim, Mochamad. 2013. Pengembangan media bimbingan. Jakarta: Akademi Pertama

Noor, Juliansyah. 2016. Metode Penelitian. Jakarta: Kencana

Romlah, Tatiek. 2006. Teori dan Praktek Bimbingan Kelompok. Malang: Universitas Negeri Malang. 
Sukardi, Dewa Ketut \& Kusmawati, Desak P.E.Nila 2008. Proses Bimbingan Dan Konseling Di Sekolah: Rineka Cipta

Sukardi, Dewa Ketut. 2010. Pengantar Pelaksanaan Program Bimbingan Dan Konseling Di Sekolah. Rineka Cipta

Singgih, Ratna Utami. 2017. Identifikasi Permasalahan Pelaksanaan Layanan Bimbingan Karir Yang Dialami Guru Bimbingan Dan Konseling Di Sekolah Menengah Kejuruan Negeri SeKota Yogyakarta. Universitas Negeri Yogyakarta

Susanti, Susi. 2016. Identifikasi Permasalahan Pelaksanaan Layanan Bimbingan Karir Yang Dialami Guru Bimbingan Dan Konseling Di Sekolah Menegah Pertama SeKecematan Depok. Universitas Negeri Yogyakarta

Sugiyono. 2015. Metode Penelitian Pendidikan. Bandung: Alfabeta

Usman, Husaini. 2011. Manajemen, Teori, Praktik, Dan Riset Pendidikan. Jakarta: Bumi Aksara.

Walgito, Bimo. 2010. Bimbingan Dan Konseling (Studi \& Karir). Yogyakarta: Andi Offset.

Wardati \& Jauhar, Mohammad. 2011. Implementasi Bimbingan dan Konseling Di Sekolah. Jakarta: Prestasi Pustaka.

Wahyuli. 2015. Studi Tentang Kompetensi Profesional Guru BK SMP Negeri Se-Kota Tarakan. Skripsi: Universitas Borneo Tarakan.

Yusuf, Syamsu \& Nurihsan, A. Juntika. 2009.
Landasan
Bimbingan
Dan
Konseling.
Bandung: Remaja
Rosdakarya. 